\title{
Experience in the Application of the Principle of Methodological Pluralism in the Study of Entrepreneurship
}

\author{
Vladimir P. Smirnov ${ }^{1} \&$ Victor G. Belkin ${ }^{1}$ \\ ${ }^{1}$ Far Eastern Federal University, Vladivostok, Russian Federation \\ Correspondence: Vladimir P. Smirnov, Far Eastern Federal University, st. Sukhanov, 8, 690091 Vladivostok, \\ Russian Federation. E-mail: vla102@yandex.ru
}

Received: October 25, 2014 Accepted: December 13, 2014 Online Published: March 16, 2015

doi:10.5539/ass.v11n7p122 URL: http://dx.doi.org/10.5539/ass.v11n7p122

\begin{abstract}
Entrepreneurship is the main domestic source of economic development. Scientific knowledge on the state of entrepreneurship is changing along with society, economy and people. The paper applied the principle of methodological pluralism and integrative approach to the study of entrepreneurship. Entrepreneurship in its development does not lose, but only changes the old characteristics. Features capital directly and immediately affect the entrepreneurship. Researchers of entrepreneurship should focus their efforts on the study of emerging forms of capital.
\end{abstract}

Keywords: entrepreneurship, research, theory, methodological pluralism, integrative approach, the new capital, additional income

\section{Introduction}

Entrepreneurship is one of the main places in the modern economy. Entrepreneurship is an important strategic resource and the main domestic source of economic development. Economic progress in the conditions of limited resources and other exhausted sources of development depends on the extent and quality of entrepreneurial activity. The study of entrepreneurship and business activity at various stages and phases of the development of society and in different sectors of the economy is an important scientific task.

\subsection{The Study of Entrepreneurship on the Classical Stage of Scientific Development}

The study of entrepreneurship begins on the classical stage of scientific development, covering a considerable period of time since the seventeenth century till the first half of the nineteenth century. At this stage in the scientific community of the true condition of obtaining knowledge about the object of study in its theoretical explanation and description is to eliminate everything that relates to the subject, its goals and values, assets and operations activities.

At the classical stage of the scientific development entrepreneurship is considered representatives of different scientific schools from different positions.

In mercantilist interpretation the entrepreneurship is:

- $\quad$ The use of trading capital;

- $\quad$ Accompanied by an increased risk form of trading activity in different product markets;

- $\quad$ The means by which the market supply comes in line with market demand.

It is estimated by the school of classical political economy, entrepreneurship is more diverse. Entrepreneurship is considered:

- $\quad$ Any highly profitable use of capital in industry, agriculture, and trade;

- $\quad$ Activities related to the establishment of new production;

- Combining and coordinating of factors of production;

- Moving resources from area with low productivity and low incomes in an area of higher productivity and profitability. 
Function of the entrepreneur different from the function of the capitalist and the functions of the control. The specific functions of the entrepreneur are:

- Connect the factors of production (capital and labor) in a single manufacturing process;

- Collection of information and the accumulation of the necessary experience;

- Economic decision-making;

- $\quad$ Start-up and implementation of the production.

Entrepreneurship is recognized as an indispensable element of effective management. The entrepreneur derives numerous benefits from its position as a mediator between all classes of producers, between producers and consumers. Entrepreneur has benefits from the fact that they know and from the fact that they do not know. Entrepreneur manages the production, is in the center of all economic relations. Already at this stage the entrepreneur is considered as the inventor and researcher in his field. Scientists notes that the attention and interest of entrepreneurs focused on the manufacture and sale of goods, on a combination of factors of production, ultimately, to the most effective use of commercial and industrial (tangible) capital.

\subsection{The Study of Entrepreneurship on the Non-classical Stage of Scientific Development}

Non-classical phase of the development of science is covering the second half of the nineteenth century and the first half of the twentieth century. At this stage, science is based on the ideas of relativity, discreteness, quantum probabilities, complementarity. This reflects to some extent the changes in the socio-economic structure of the advanced countries. Company proceeds to step industrial development. In the economy is set dominance of monopolies, developing into the domination of finance capital. In the production technology has consistently approved by the third and fourth technological orders (Glazyev, 1993). With the transition to machine production is increasing the role of consumption. In economic studies becomes dominant approach from the perspective of the marginal utility of wealth and the marginal productivity of factors of production. Dominant position in economics takes the neoclassical theory. The most significant contribution to the development of the foundations of the theory of entrepreneurship at this stage are the ideas of Schumpeter. Schumpeter recognized as the founder of the evolutionary trend in economic science. Its merit is to validate the approach to entrepreneurship as a major factor of economic development. According to him, the engine of economic development and the cause of the cyclic process of structural changes produced in the economy, is the innovation of entrepreneurs. Based on the entrepreneurship it is possible overcome the inertia of the economic system. Entrepreneur is an innovator, a key player in the system, serving as a realization of innovations. His work is the basis of economic development, that is, the transition of the economy from one equilibrium state to another. The development is "the implementation of new combinations" of existing in the relevant field of things and forces. It covers the five cases: 1) the production of new, unknown to consumers benefits or changing the quality of the well-known benefits; 2) application of a new mode of production, or method of commercial use good; 3) development of a new market; 4) development of a new source of raw materials (semi-finished products); 5) organizational change (break the monopoly power of entity or the creation of its monopoly). The entrepreneur puts the correct forecast, commits an act of thinking to design a new activity, creates a new activity aimed at producing a new type of product (Schumpeter, 1982, p. 159).

At this stage of the development of science in the economic structure of industrial society is determined by the entrepreneurship, on the one hand, as income-generating activities as a result of the unique abilities of the entrepreneur to innovate, finding unexploited opportunities, combining the factors of production, activities with the risk in the different areas of the economy. On the other hand, entrepreneurship is seen as searching and exploring new opportunities, as the driving force of development, as an internal source of not only economic growth, but also social and economic development in general. In the center of the attention and interest of entrepreneurs are not only the availability of goods and factors of production, but, above all, the unmet needs and investment opportunities, the implementation of which involves the use of financial capital.

\subsection{The Study of Entrepreneurship on the Postnonclassical Stage of Scientific Development}

Postnonclassical stage in the development of science begins in the second half of the twentieth century and covers the modern period. Qualitative changes occur in scientific research. At this stage of science is based on the paradigm of emergence and self-organization, "open rationality," focuses on the historical time, integrity, synergy and development as the most important characteristics of being. Science seeks to explain not only the processes taking place in society (the transition to post-industrial society), in the economy, entrepreneurship, but also anticipate their development in order to prepare humanity for the coming changes. 
Foreign and domestic experts at this stage of the development of science on the basis of the achievements of their predecessors provide estimates of the development of the theory of entrepreneurship, assess the achieved level of scientific knowledge in a given subject area, provide increased scientific knowledge about entrepreneurship. Researchers have noted the complexity and multidimensionality of understanding entrepreneurship. This can be explained by the fact that entrepreneurship in its development does not lose, but only modifies the previous characteristics, and at the same time constantly acquiring additional properties.

According to experts the modern entrepreneurship is:

- Scope of society, in which progressive economic change begins;

- The most dynamic element of the economic system;

- The economic process of self-renewal of a creative personality (the creative team);

- The most profitable type of business;

- Type of economic activity, which is characterized by high efficiency;

- Activities to develop new sources to meet the needs, the creation of a new consumer demand, the production of new economic benefits;

- Activity of independent, free business entities systematically using innovation working in various sectors of the economy, choosing under uncertainty and risk her own line of conduct, implementation of inaccessible to other economic opportunities.

The study of modern approaches to business allows you to mark an increment of theoretical knowledge of entrepreneurship in the context of the object, the subject and the methods of scientific knowledge. Therefore, we should agree with the conclusion of the inadequate development of the theory of entrepreneurship.

Scientific knowledge on the state of entrepreneurship is changing along with society, economy and people. A scientific theory is a set of interrelated scientific concepts and judgments, reflecting a stable relationship between the phenomena and processes of reality. Elements of a scientific theory of entrepreneurship appear at early stages of economic science. These elements are further enhanced and deepened with the development of society, economy, business and science. In these circumstances, it is advisable to pursue the research, maintain successful direction.

\section{Methods}

To achieve results in the current research is necessary to follow the principle of methodological pluralism, which is to recognize, on the one hand, the one-sidedness of any methodology, on the other hand, the usefulness of alternatives (Feyerabend, 1986). Experts acknowledge the possibility of applying this principle in the study of economic phenomena and processes (Flaschel, 2009). Scientific knowledge of the entrepreneurship, in our opinion, should be based on this principle by using advanced modification of the system approach. Modern modification of the systems approach is integrative approach. Systematic approach becomes an integrated character when he organically includes a functional, situational, target, reflexive and other methodological approaches. Experience of using a reflexive approach to the study of entrepreneurship is available (Smirnov, 2014). The using of the integrated approach in the historical aspect can be represented as a movement of thought in the spiral.

\section{Results}

In the modern society and in the modern economy entrepreneurship serves as a generator of social and economic progress. The position about this role of entrepreneurship can be deduced from the theory explaining the economic progress of the expanding markets (Makarov, 2010, p. 12). This theory, in our opinion, as a supplement manifested in the industrial economy and in the emerging post-industrial economy in broadening the sources of creation and applications of new capitals (capitalization elements of economic activity). In our opinion, the basis of deep market expansion is a quantitative and qualitative change in the capital - means bringing entrepreneur flows of goods and income. Understanding of capital varies with its development and the change in its role in the economy and society. Simultaneously, the understanding of entrepreneurship is changed. The essence of entrepreneurship is to create a new capital in order to obtain business income (Smirnov, 2014, p. 305).

Application of the principle of methodological pluralism and application of modern modification of the system approach makes it possible not to eliminate, as previously happened in the discussions of the representatives of 
different scientific schools, and to maintain and develop good ideas and achievements of various researchers capital and entrepreneurship as well as to link the development of capital and entrepreneurship.

\section{Discussions}

Representatives of the school mercantilists explore trade capital and monetary capital (Mercantilism, 1933, p. 155). Entrepreneurship is defined as the use of commercial capital and risky activities to bring the proposal in line with demand.

However, representatives of the school of the Physiocrats believe that capital is a factor of production, constantly reproducible means of production which used in agriculture (Quesnay, 1960, p. 104).

A. Marshall argues that the capital is part of the wealth of the individual, which is used to generate income (Marshall, 1961). In accordance with the principle of substitution the entrepreneur replaces less productive combination of factors of production to more productive combination, ensures the advancement of technology and organization of a separate company, expands production possibility of society.

J. Schumpeter called capital "fund of purchasing power", consisting of cash and payment obligations, and providing the progressive development of society (Schumpeter, 1982, pp. 231, 169-170).

In the economy of post-industrial society the role of entrepreneurship is enhanced. Separate consideration of factors of production (labor, capital and land) belonging to different owners, ceases. All production factors are combined into a single concept - the capital (the mean of obtaining goods). And in the structure of this single capital is released various functional elements (forms) necessary to deliver to entrepreneur specific goods which are to be used in production. At the same time there are new kinds of entrepreneurship.

Scope of the intellectual entrepreneurship expands. Human capital, organizational capital and customer capital are its parts.

Human capital theory is being developed (Schultz, 1961; Becker, 1964; Denison, 1962). R. Kapelyushnikov writes: "The human capital "is commonly understood as the stock of knowledge, skills and abilities of any person, which can be used both in production and in consumer applications" (Kapelyushnikov, 2013, p. 29). By definition proposed by OECD experts, human capital is "the knowledge, abilities and skills embodied in individuals that enable them to create a personal, social and economic well-being" (OECD, 2001).

A. Buzgalin and A. Kolganov give explanation of the process of development of human capital theory. According to them, in a modern economy and neoclassical economics "emerged to the forefront of the creative qualities of man are objectively transformed into private property, which the corporate capital will seek to adopt (or at least used), pulling on the creative personality mask of" capital "(Buzgalin \& Kolganov, 2006, p. 141).

Important for the theory of entrepreneurship is the concept of social capital, which is developing R. Putnam (Putnam, 1996), J. S. Coleman (Coleman, 2001) and Bourdieu (Bourdieu, 2002). Social capital appears, on the one hand, as the characteristic of the institutional environment, on the other hand, is a characteristic of a particular resource stock entity. The true "social capital" as a particular locality climate of trust and loyalty between members of the industrial community, employers and workers once wrote A. Marshall (Marshall, 1961). J. Schumpeter also uses the term "social capital", giving it the following meanings: "the total of all private capital also gives us some information: it shows the value of the fund, which may be available to employers, the extent of economic power, which is aimed at then to extract the means of production of the previous areas of their application " (Schumpeter, 1982, p. 240).

Representative of the new economic sociology M. Granovetter considers economic actions as socially rooted, adjustable or social institutions, or social networks. According to his estimates the social network of entrepreneurs, based on the weak links are more competitive than the networks based on strong ties (Granovetter, 2004). This theory based on the provisions set forth K. Polanyi and O. Williamson. These provisions are the following: economic order is usually a function of the social order (Polanyi, 1993, p. 13); economic agents base their activities on the vested interests that is implemented by the opportunistic behavior that generates the bulk of the transaction costs in economic activities to be overcome either by using market mechanisms, either through hierarchies (Williamson, 1995, pp. 33-53). Social institutions provide a framework of economic activities, define a core set of its subjects, set cost-effectiveness for different population groups, fixed territorial extent and temporal duration of the interaction of economic agents with each other. M. Granovetter's work initiated the study of the characteristics, role and implications of the social networks of entrepreneurs in the economy (Aldrich \& Zimmer, 1986). 
B. Kornejchuk defines capital as a means of providing a flow of benefits to the individual in the future. As functional elements of capital it allocates external capital (the set of objects that can generate a flow of benefits without the direct involvement of the owner), domestic capital (the quality of the individual that affect the flow it receives benefits), social capital (the system of relations of the individual with others, which influences the flow it receives goods), as well as the creative capital (set of personal qualities of the person, which allow him to exercise the highest activity) (Kornejchuk, 2006, pp. 129-131).

V. Radaev delineates the economic, physical, cultural, human, social, administrative, political and symbolic capital as special forms of capital, affecting the person's position in society. In this case, under the accumulated capital is understood as an economic resource that is involved in the processes of reproduction and increase in cost by mutual conversion of its diverse forms (Radaev, 2003).

Y. Razumova allocates capital according to the form of participation in the investment process and innovation. She proposes to consider the following forms of capital: organizational, administrative, logistical, and intellectual information, natural resources, spiritual, psychological, geopolitical, cultural and historical capital (Razumova, 2008).

Y. Osipov considers power capital as the material basis of economic power entrepreneur. Power capital exercises its power beyond itself and beyond the purely competitive market organization. It organizes not only its own movement, but also the functioning of the environment, other capital, social and economic parameters, local and general processes (Osipov, 1995, p. 372).

Various approaches for determining capital supplement each other. The features of capital directly and immediately affect the entrepreneurship.

\section{Conclusion}

Capital can take many forms, retaining its essential features. Essential features of the capital following. These are:

- Limited economic resources;

- Accumulated economic resources;

- Resource with specific liquidity, ability to turn into cash;

- The cost, bringing new value.

Different forms of capital are the following common features:

- Connect the factors of production (labor and materials, information, scientific knowledge);

- Productive consumption;

- Generation cost;

- Continuity of the reproduction.

Features capital directly and immediately affect the entrepreneurship. Efforts to establish a new capital is the cause of the expansion of markets, the progress of the economy and society. This is most clearly manifested in the post-industrial society. As a result of the activity of entrepreneurs of business income, as well as resources, factors, conditions, forms, methods, means of activity over time are capitalized and start bringing revenue streams, that is, converted to forms of capital. Qualitative improvement of the components of capital is also a boon to an entrepreneur and a unique form of business income.

Scientists should focus their efforts on the study of new forms of capital. These forms will appear as a result of the conversion factors, conditions, methods and means of production activities into new forms of capital.

\section{References}

Aldrich, H., \& Zimmer, C. (1986). Entrepreneurship trough social networks. In D. Sexton, \& R. Smilor (Eds.), The Art and Science of Entrepreneurship (pp. 3-23). Cambridge: MS.

Becker, G. (1964). The human capital. Chicago: University of Chicago Press.

Bourdieu, P. (2002). The forms of capital. Economic Sociology, 3(4), 60-74.

Buzgalin, A., \& Kolganov, A. (2006). Man, market and invest in the 21 st century economy. Economic Issues, 3 , $125-141$.

Coleman, J. (2001). Social and human capital. Social Sciences and Modernity, 3, 122-139. 
Denison, E. (1962). The sources of economic growth in US and alternative befour US. NY.

Feyerabend, P. (1986). Selected papers on the methodology of science. Moscow: Progress.

Flaschel, P. (2009). The macrodynamics of capitalism: Elements for a syntehesis of Marx, Keynes and Shumpeter (2nd ed.). Berlin.

Glazyev, S. Y. (1993). Theory of long-term technical and economic development (p. 310). Moscow: VLADAR.

Granovetter, M. (2004). Economic institutions as social constructs: the framework for analysis. Journal of Sociology and Social Anthropology, 7(1), 76-89.

Kapelyushnikov, R. (2013). How much is the human capital of Russia? Part 1. Economic Issues, 1, 27-47.

Kornejchuk, B. V. (2006). Information economy. Tutorial. St. Petersburg: Peter.

Makarov, V. L. (2010). Formation of a knowledge economy: concepts and issues. In B. Z. Milner (Ed.), Innovative development: Economy, intellectual resources, knowledge management (pp. 11-26). Moscow: Infra-M.

Marshall, A. (1961). In C. W. Guillebaud (Ed.), Principles of economics (Vol. 1. 9th ed.). London: Macmillan.

Mercantilism. (1933). Leningrad.

OECD. (2001). The well-being of nations: the role of human and social capital. Paris: OECD.

Osipov, Y. M. (1995). Theory of economy (Vol. 1). Moscow.

Polanyi, K. (1993). Self-regulating market and the fictitious commodities: labor, land and money. THESIS, 1(2), $10-17$.

Putnam, R. (1996). Who killed civic America? Prospect. March.

Quesnay, F. (1960). Selected economic works. (Ed. A. I. Casarin. Trans.). Moscow.

Radaev, V. V. (2003). Concept of capital, forms of capital and their conversion. Social Sciences and Modernity, 2, 5-16.

Razumova, Y. (2008). Institute of innovation and investment process in the system of social reproduction: development and formation. Moscow: Information and innovation center "Marketing".

Schumpeter, J. (1982). Theory of economic development (p. 455). Moscow: Progress Publisher.

Schultz, T. W. (1961). Investment in human capital. American Economic Review, 51(1), 1-17.

Smirnov, V. P. (2014). Using scientific reflection in the study of entrepreneurship. Life Science Journal, 11(9s), 303-306.

Williamson, O. (1995). The vertical integration of production: Considerations about market failures. In V. M. Halperin (Ed.), Theory of the firm. Saint Petersburg: School of Economics.

\section{Copyrights}

Copyright for this article is retained by the author(s), with first publication rights granted to the journal.

This is an open-access article distributed under the terms and conditions of the Creative Commons Attribution license (http://creativecommons.org/licenses/by/3.0/) 